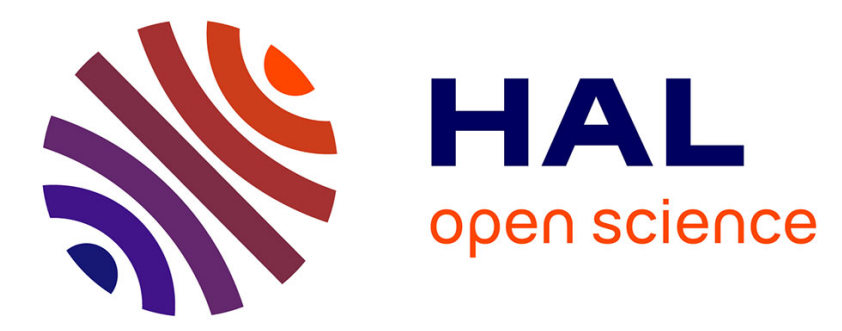

\title{
Hydrological parameter estimation for ungauged basin based on satellite altimeter data and discharge modeling: a simulation for the Caqueta River (Amazonian Basin, Colombia)
}

\author{
J. G. Leon, F. Seyler, S. Calmant, Marie-Paule Bonnet, M. Cauhopé
}

\section{To cite this version:}

J. G. Leon, F. Seyler, S. Calmant, Marie-Paule Bonnet, M. Cauhopé. Hydrological parameter estimation for ungauged basin based on satellite altimeter data and discharge modeling: a simulation for the Caqueta River (Amazonian Basin, Colombia). Hydrology and Earth System Sciences Discussions, 2006, 3 (5), pp.3023-3059. hal-00330792

\section{HAL Id: hal-00330792 \\ https://hal.science/hal-00330792}

Submitted on 21 Sep 2006

HAL is a multi-disciplinary open access archive for the deposit and dissemination of scientific research documents, whether they are published or not. The documents may come from teaching and research institutions in France or abroad, or from public or private research centers.
L'archive ouverte pluridisciplinaire HAL, est destinée au dépôt et à la diffusion de documents scientifiques de niveau recherche, publiés ou non, émanant des établissements d'enseignement et de recherche français ou étrangers, des laboratoires publics ou privés. 
Hydrol. Earth Syst. Sci. Discuss., 3, 3023-3059, 2006 www.hydrol-earth-syst-sci-discuss.net/3/3023/2006/

(C) Author(s) 2006. This work is licensed under a Creative Commons License.
Hydrology and Earth System Sciences Discussions

Papers published in Hydrology and Earth System Sciences Discussions are under open-access review for the journal Hydrology and Earth System Sciences

\section{Hydrological parameter estimation for ungauged basin based on satellite altimeter data and discharge modeling. A simulation for the Caqueta River (Amazonian Basin, Colombia)}

HESSD

3, 3023-3059, 2006

Hydrological parameter from satellite altimeter data

J. G. Leon

\section{Title Page}

Abstract

Conclusions

Tables

14

4

Back

Full Screen / Esc

Printer-friendly Version

Interactive Discussion 


\section{Abstract}

The main objective of this paper is to review the usefulness of altimetric data in ungauged or very poorly monitored basin. It is shown that altimetric measurements can be combined with a single in-situ gauge to derive a reliable stage-discharge relation5 ship upstream from the gauge. The Caqueta River in the Colombian Amazon Basin was selected to simulate a poorly monitored basin. Thus it was possible to derive the stage-discharge relationship for 13 "virtual gauge stations" defined at river crossing with radar altimetric ground tracks. Stage measurements are derived from altimetric data following the methodology developed by Leon et al. (2006). Discharge is modeled using PROGUM - a flow routing model based on the Muskingum Cunge (M-C) approach considering a diffusion-cum-dynamic wave propagation (Leon et al., 2006 ${ }^{1}$ ) using a single gauge located downstream from the basin under study. Rating curve parameters at virtual stations are estimated by fitting with a power law the temporal series of water surface altitude derived from satellite measurements and the modelled discharges. The methodology allows the ellipsoidal height of effective zero flow to be estimated. This parameter is a good proxy of the mean water depth from which the bottom slope of the reaches can be computed. Validation has been conducted by comparing the results with stages and discharges measured at five other gauges available on the Caqueta basin. Outflow errors range from $10 \%$ to $20 \%$ between the upper basin and the lower basin, respectively. Mean absolute differences less than $1.10 \mathrm{~m}$ between estimated equivalent water depth and measured water depth indicates the reliability of the proposed method. Finally, a $1.2 \times 10^{-4} \mathrm{~m} \mathrm{~m}^{-1}$ mean bottom slope has been obtained for the $730 \mathrm{~km}$ long reach of the Caqueta main stream considered.

\footnotetext{
${ }^{1}$ Leon, J. G., Bonnet, M. P., Cauhope, M., Calmant, S., and Seyler, F.: Distributed water flow estimates of the Upper Negro River using a Muskingum-Cunge routing model constrained by satellite altimetry, J. Hydrol., submitted, 2006.
}

HESSD

3, 3023-3059, 2006

\section{Hydrological parameter from satellite altimeter data}

J. G. Leon

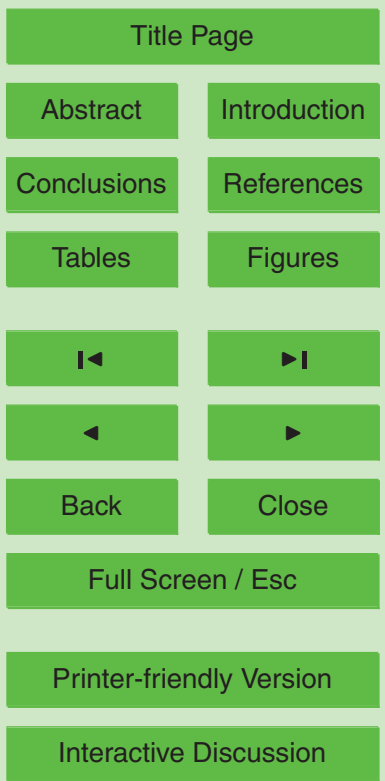




\section{Introduction}

The Caqueta River is the most important river of the Colombian Amazon Basin. No previous hydrological modelling has been reported for the area. Modelling studies of the Amazon Basin have mostly dealt with the Amazon main stem (Costa and Foley, 5 1997; Coe et al., 2002; Costa et al., 2002), and major tributaries of the Amazon in Brazil. These studies focused mainly on water balance models based on climatologic data such as gridded precipitation and temperature and water transport models to estimate the river discharge and flooded area of the basin. These attempts have been limited due to the rough scale of the gridded climatologic data available. Previous hydrodynamical modelling estimated discharge for the Amazon main stream through use of a flow routing model based on the Muskingum method (Richey et al., 1989) and for the Negro river (Leon et al., $2006^{1}$ ), a northern tributary joining the Solimões in Manaus to form the Amazon. The Negro river basin has been chosen because it is not quite as steady as the Amazon mainstem, but it is relatively well-monitored, with about twenty gauged stations distributed over the $715000 \mathrm{~km}^{2}$ basin area. In that part of the basin where discharges and water stages were available for a period of time including the altimetry satellite acquisition period (i.e. from 1992 onwards), water transport was simulated using a Muskingum-Cunge (M-C hereafter) flow routing model based on a diffusion-cum-dynamic wave propagation assumption. Therefore, discharges were predicted over the upstream part of the catchment, from Cucui, the northernmost gauging station on the Negro River at the border of Venezuela and Columbia, and from Uarucu, the most upstream gauging station on the Uaupes, a west - east tributary of the upper Negro River. The downstream limit of this modelling study was Serrinha, which is the last gauging station to have discharge records when going dowstream the $\mathrm{Ne}$ stage-discharge relationships.

Flood propagation has been applied to each river section comprised between two insitu gauging stations. Radar altimetry data have first been used to estimate the altitude

HESSD

3, 3023-3059, 2006

Hydrological parameter from satellite altimeter data

J. G. Leon

Title Page

Abstract Introduction

Conclusions

Tables

References

Figures

14

4

Back

Close

Full Screen / Esc

Printer-friendly Version

Interactive Discussion 
of the in situ gauging stations involved in the modelling as none of them had been topographically levelled (Leon et al., $2006^{1}$ ). This prevented hydrodynamical modelling as the slope between river gages has to be known for running most models. This study showed a very good agreement between estimated and measured discharges (mean $5 \mathrm{rms}<10 \%$ ). The first objective of that study was to distribute the flow, at any point in the river stream to estimate discharge at virtual gauging stations, defined as the crossing of the river channel by the radar satellite ground tracks (Frappart et al., 2005; Leon et al., 2006).

This method was used to establish stage-discharge relationships between satellite10 derived water level from TOPEX/Poseidon (T/P hereafter) and ENVISAT measurements and estimated river discharges at virtual stations. Expressing the local stagedischarge relationship as a simple mathematical function, from remote discharge estimated by flow routing model and local stage from radar altimeter, the local flow conditions can be expressed in terms of stage or vice versa. Leon et al. (2006) have 5 proposed a bibliographic review of the recent use of radar altimetry to monitor continental water bodies (continental seas, then lakes and large rivers). Usually, land water scientists have to deal with dataset primarily collected and processed for ocean research (T/P, Jason, GFO, part of ERS 1 and 2 and ENVISAT) or ice caps (ERS 1 and 2, ENVISAT, ICEsat). In this study T/P and ENVISAT measurements have been found to present an overall uncertainty over continental waters of a couple of decimeters for the first one (Birkett et al., 2002) and of the a decimeter for the second based on its retracking algorithm ICE1 (Frappart et al., 2006). Another evaluation tool for both altimetric stages and modeled discharges turned out to be the stage-discharge relationship itself, which was found to be adequate in most cases (in particular for the 25 ENVISAT virtual gauging stations) to retrieve the river mean depth defined as the altimetric height equivalent to the zero flow (Leon et al., 2006). With this method it was then tested that radar altimetry can efficiently be used to model the water propagation in a relatively well-monitored environment as the Brazilian part of the Amazon basin. The main interest of the method lies in the multiplication the monitoring points, the

\section{HESSD}

3, 3023-3059, 2006

\section{Hydrological parameter from satellite altimeter data}

J. G. Leon

Title Page

Abstract Introduction

Conclusions

Tables

References

Figures

14

4

Back

Full Screen / Esc

Printer-friendly Version

Interactive Discussion 
virtual altimetric gauging stations being about ten times the number of in situ gauging stations. In other words, water flow can be distributed in smaller sub-basins than the areas defined only from in-situ gauged stations.

Then, the use of altimetric data for hydrological modeling purposes was adressed: 5 what is the usefulness of altimetric data in a really ungauged or poorly monitored basin? Can water discharge be accurately evaluated in this case?

The Caqueta River Basin, which is part of the Amazon Basin in Colombia has been chosen. This river drains the Andean piemont up to the Amazonian plain where it becomes the Japura river in Brazil. Unike the Brazilian part of the Amazon basin, the 10 hydrologic data cannot be accessed via the internet. 26 out of the 32 gauged stations were abandoned before the eighties. Only the six rem aining stations belonging to the Colombian hydrologic network institute (IDEAM) can provide data. This is typical of the situation prevailing in countries sharing the Amazon Basin, except Brazil. The objective was to model propagation with the method previously developed for the Negro

River basin, using only one in situ gauging station located dowstream from the river, to determine stage discharge relationship at the virtual altimetric virtual stations, as well as mean depth river bed. The 5 other stations providing stage and discharge enable us to evaluate the precision obtained during the simulation of a poorly gauged basin.

In this paper, the zone under study as well as the main characteristics of the in-

situ and altimetric data available are presented. The methods used i) for predicting remote discharges at virtual stations based on the M-C flow routing model and in-situ data using PROGUM (already reported in Leon et al., 2006 ${ }^{1}$; and ii) for establishing stage-discharge relationships between satellite-derived water level and river discharge reported in Leon et al. (2006) are summarized. It is shown that both methods allow us to estimate the base of the equivalent wet section depth of the river, referred to here as the average water depth. Finally, the resulting bed channel slope for the Caqueta main stream is presented.
HESSD

3, 3023-3059, 2006

\section{Hydrological parameter from satellite altimeter data}

J. G. Leon

Title Page

Abstract Introduction

Conclusions

Tables References Figures

14

4

Back

Full Screen / Esc

Printer-friendly Version

Interactive Discussion 


\section{Material and methods}

\subsection{Caqueta River level and discharge data}

HESSD

The Caqueta River drains an area of some $200000 \mathrm{~km}^{2}$ from $2.24 \mathrm{~N}$ to $1.77 \mathrm{~S}$ latitude and from $76.57 \mathrm{~W}$ to $69.43 \mathrm{~W}$ longitude (Fig. 1). Its source is to the East of the Andes

5 Mountains. Then it flows through the Amazon basin over $1270 \mathrm{~km}$ to the border between Brazil and Colombia where it becomes the Japura River. Discharge at this point ranges from about $1500 \mathrm{~m}^{3} / \mathrm{s}$ to $33000 \mathrm{~m}^{3} / \mathrm{s}$. Mean annual temperature is about $26^{\circ} \mathrm{C}$ with differences of less than $5^{\circ} \mathrm{C}$ between average monthly extremes. Annual rainfall ranges from $3000 \mathrm{~mm}$ to $4000 \mathrm{~mm}$. There is no dry season but a unimodal regime and

10 a rainfall peak between April and June.

Thirty two gauged hydrological stations are located along the Caqueta River main stream. However, only six provide sufficient data to be included in the study (Table 1). The other stations were abandoned before 1980. This is typical of the current situtation with IDEAM (Institute of Hydrology, Meteorology and Environmental Studies of Colombia). Most stations were abandoned for economic reasons and social conflicts in the country. Thus, the use of virtual gauged stations, based on the proposed methodology, would help complete and reinforce the current IDEAM network monitoring the Colombian in-land waters.

The stations that we considered in this study are reported in Table 1, from Guaquira to Villa Betancourt stations accounting for a total length of $730 \mathrm{~km}$ (Fig. 1). Among them, only Vila Betencourt was used in the modelling process, the other five being used for validation. Unfortunately, there are not more in-situ information available upstream of Guaquira station.

\subsection{In-Situ data}

Daily measurements of the river water stage were collected from January 1995 to December 2000 for all stations, except for Villa Betancourt, along the basin outlet, for

Hydrological parameter from satellite altimeter data

J. G. Leon

Title Page

Abstract Introduction

Conclusions

Tables

References

Figures

14

4

Back

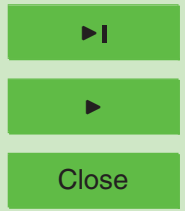

Full Screen / Esc

Printer-friendly Version

Interactive Discussion 
which daily discharge measurements spanned from March 1980 to March 2004. Daily water levels as well as periodical measurements of cross sectional area, water surface width, flow velocity and bed channel depth (taken at the same time) were obtained from the IDEAM data base.

\section{$5 \quad 2.3$ Satellite altimetry data}

Usually, water level height relative to the reference ellipsoid is measured by estimating the distance between satellite and water surface as measured by the altimeter radar and the satellite altitude relative to the same reference ellipsoid estimated by orbitography techniques. The radar altimeter on board the spacecraft overflies a given

10 region at regular intervals or repeat cycles. The ground track footprint varies depending on orbit characteristics. In this study, two satellite data sources have been selected: Topex/Poseidon (T/P) and ENVISAT missions.

Only propagation and geophysics corrections were applied including ionospheric refraction, dry tropospheric refraction, wet tropospheric refraction, solid earth and pole tide, ocean tide loading, inverted barometer effect and sea state bias were not considered.

The main characteristics of T/P and ENVISAT missions are listed in Table 2.

\section{River water stage from altimetry data selection}

Altimeter measurements from space are affected by continental topography, vegetation, ice and snow cover. In our case, ice and snow cover were not considered. In the case of topography the altimeter may lock off and it may take some time before

it locks on again. As a result, the information provided may not be reliable. Also, geometric errors tend to occur when the altimeter radar remains locked on water while the satellite already is well ahead (Frappart et al, 2006), since the reflected signal on water has more power than that on land.
HESSD

3, 3023-3059, 2006

Hydrological parameter from satellite altimeter

data

J. G. Leon

Title Page

Abstract Introduction

Conclusions

Tables

References

Figures

14

4

Back

Close

Full Screen / Esc

Printer-friendly Version

Interactive Discussion 
The distribution over time of the radar echo, known as waveform, is complex and can exhibit multi-peaks (Berry, 2003; Birkett, 1998) rather than a single brad peak typical of ocean surfaces. Moreover, the existing T/P and ENVISAT retracking algorithms, customized for ocean surfaces, are not supposed to process these signals. Consequently, 5 the precision of the altimetric height is reduced. As far as ENVISAT data are concerned, we chose the measurements tracked by ICE1. Frappart et al. (2006) have shown that the tracker ICE1 was best suited to retrieve the ellipsoid height of continental water bodies.

Following the method proposed by Leon et al. (2006), we used JERS mosaic images 10 March to April 1996 in order to select altimeter data at the nadir of water bodies only. Thus, potential contamination of the T/P and ENVISAT signal by land reflection can be minimized, while securing an adequate number of altimeter measurements on water. Indeed, based on this mosaic, the most adequate satellite tracks - river intersections 15 can be selected with a high spatial resolution. Figure 2 shows an example of data selected to define the so-called virtual stations.

Finally, daily mean altimetric water levels were obtained based on the median of the data set. Frappart et al. (2006) have shown that the median of measurements for each pass is a better estimate of water stage than the mean. Unrealistic median values were eliminated by visual comparison of water level and discharge time series for a given virtual station.

\subsection{Discharge data at virtual stations}

As mentioned at the beginning of this paper, discharge at virtual stations was estimated using PROGUM, a M-C flow routing model with diffusion-cum-dynamic wave 25 propagation assumption and in-situ discharges. The $M-C$ flow routing model (Cunge, 1969) is an improvement of the classical Muskingum model. In this method, the wellknown routing parameters of Muskingum $X$ and $K$ are derived from readily measurable hydraulic data: free water slope, channel width, wave velocity, and reach length,
HESSD

3, 3023-3059, 2006

\section{Hydrological} parameter from satellite altimeter data

J. G. Leon

Title Page

Abstract Introduction

Conclusions

Tables

References

Figures

14

4

Back

Close

Full Screen / Esc

Printer-friendly Version

Interactive Discussion

EGU 
rather than historic flow discharge data (Ponce et al., 1996). Ponce (1986) showed the benefits of using $M-C$ algorithm with the lateral inflow added for implementing a representation of diffusive waves.

Leon et al. (2006) ${ }^{1}$ have developed, tested and validated the PROGUM model over 5 the upper Negro River mainstream. They estimated the discharges at different virtual stations from Cuicui to Serrinha gauged stations. Unlike the aforementioned research, discharge at virtual stations shown in Fig. 3 was estimated using only daily in-situ measurements between 1980 and 2004 from the last local station in the Caqueta main stream (Villa Betancourt). Discharge of the main tributaries and upstream input hydrogram were estimated for the same period based on the drainage influence area. Application of the method is completely detailed in Leon et al. (2006) ${ }^{1}$.

The $\mathrm{M}-\mathrm{C}$ model is governed by the following equation:

$O_{t+1}=C_{0} \cdot I_{t+1}+C_{1} \cdot I_{t}+C_{2} \cdot O_{t}+C_{3} Q_{L}$

Where $I_{t}$ is the inflow discharge, $O_{t}$ the outflow discharge at time $t$ and $Q_{L}$ the average lateral inflow rate $\left(Q_{L}=q_{L} . \Delta x\right.$, where $\Delta x$ is the reach length.). Eq. (1) is flow routing for the M-C method, where:

$c_{0}=\frac{(-K X+0.5 \Delta t)}{(K-K X+0.5 \Delta t)}$

$C_{1}=\frac{(K X+0.5 \Delta t)}{(K-K X+0.5 \Delta t)}$

$c_{2}=\frac{(K-K X-0.5 \Delta t)}{(K-K X+0.5 \Delta t)}$

$C_{3}=\frac{\Delta t}{(K-K X+0.5 \Delta t)}$

HESSD

3, 3023-3059, 2006

Hydrological parameter from satellite altimeter data

J. G. Leon

Title Page

Abstract Introduction

Conclusions

References

Tables

Figures

14

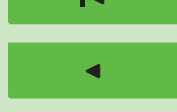

Back

Close

Full Screen / Esc

Printer-friendly Version

Interactive Discussion 
Where, $\Delta t$ is the time step. The $K$ and $X$ coefficients are calculated by PROGUM as follows:

$K=\frac{\Delta x}{c}$

$X=\frac{1}{2}\left(1-\left[(\beta-1)^{2} F^{2}\left(\frac{q}{\text { So.c. } \Delta x}\right)\right]\right)$

5 Where $c$ is the flow celerity, $\beta$ a coefficient relating average velocity and celerity, $\mathrm{F}$ the Froude number, $q$ the unit-width discharge and $S o$ the free water slope.

\section{Error estimation}

10 To infer modelling errors between measured discharge and estimated discharge at gauged in-situ stations, two formulations have been used:

$E_{1}=\frac{\left|Q_{\text {cal }}-Q_{\text {meas }}\right|}{Q_{\text {meas }}}$

$E_{2}=\frac{\left|Q_{\text {cal }}-Q_{\text {meas }}\right|}{\left|Q_{\text {min }}-Q_{\text {max }}\right|}$

$E_{1}$ stands for the mean absolute error based on measured outflow $\left(Q_{\text {cal }}\right.$ is the calcu15 lated outflow and $Q_{\text {meas }}$ is the measured outflow) and $E_{2}$ is the mean absolute error based on the maximum $\left(Q_{\max }\right)$ and minimum $\left(Q_{\min }\right)$ measured flow difference.

These estimations are applied to compare in-situ measured outflows and estimated outflows. In our study, these results are compared at six in situ stations listed in Table 1.

2.5 Rating-Curve and water depth estimations at virtual stations

20 Stage-discharge relationship or rating curve for gauging stations are developed using a set of discharge measurements and the corresponding water level. Derived from Man-

HESSD

3, 3023-3059, 2006

Hydrological parameter from satellite altimeter data

J. G. Leon

Title Page

Abstract Introduction

Conclusions

References

Tables

Figures

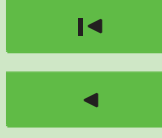

$\rightarrow$

Back

Close

Full Screen / Esc

Printer-friendly Version

Interactive Discussion

EGU 
ning equation (Rantz, 1982; Leon et al., 2006), this relationship expresses discharge as follows:

$Q_{t}=a(H-z)_{t}^{b}$

Where $Q_{t}$ is the discharge and $(H-Z)_{t}$ stands for the water depth of the control section 5 at time $t$. Normally, $a$ and $b$ coefficients are specific to a channel cross-section and can be related to the physical characteristics of the river. $a$ is a scaling factor that encompasses the section width, the local bottom slope and Manning coefficient. $b$ includes the geometry of the river banks, in particular the departure from vertical banks and, generally, it is an indicator of the type of control acting on the stage-discharge relation. Leon et al. (2006) have proposed a detailed review of the main concepts and hypotheses to derive the relationship between stage and discharge.

Standard rating curves are computed using water depth measurements with respect to the bottom of the river bed. In the case of altimetry data, $H$ in Eq. (6) is the height of the water surface with respect to a reference ellipsoid. To convert these heights into water depths, a parameter is included in the regular formulation of stage-discharge relationship, namely $z$, which stands for the elevation of the effective zero flow with respect to the ellipsoid. It is worth noting that a rating equation such as Eq. (6) is developed for each river channel or cross-section and not be expected to be applicable to any other river location. This is because the change in depth is used as an index corresponding to a change in width and velocity, and is specific to the channel characteristics of the reach being measured (Bjerklie et al., 2003). In turn, the successive $z$ values provide many esitmates of the along-stream change in river depth and elevation.

Taking $Q$ and $h$ as known measured values, one has to arrive at the value of $z$ that allows the water depth to be estimated from the zero flow of the channel at time $t$ any range of discharges Leon et al. (2006) proposed a methodology based on the minimization of RMSE (Root Mean Square Error) between the modeled or measured

HESSD

3, 3023-3059, 2006

Hydrological parameter from satellite altimeter data

J. G. Leon

Title Page

Abstract Introduction

Conclusions

Tables

References Figures

14

4

Back

Full Screen / Esc

Printer-friendly Version

Interactive Discussion 
discharge and the rated discharge. The RMSE can be expressed as follows:

RMSE $=\sqrt{\frac{\sum\left(Q_{\text {mes }}-Q_{\text {calc }}\right)^{2}}{n}}$

HESSD

Where, $Q_{\text {mes }}$ is the measured flow in the case of the gauge or the modeled discharge in the virtual gauge case, $Q_{\text {calc }}$ is the rated flow and $n$ the number of measurements 5 considered.

The $a$ and $b$ coefficients are estimated using a linear regression through the $(\mathrm{Ln}(\mathrm{Q}), \mathrm{Ln}(\mathrm{H}-\mathrm{z})$ ) set for a given $z$. Exploring the range of possible values of $z$ allows the function $\operatorname{RMSE}(z)=f(z)$ to be built up. As proposed by Leon et al. (2006), the entire range of possible $z$ values has been explored by increments of $0.01 \mathrm{~m}$. The value of $z$ 10 representing the effective zero flow altitude is such that:

$\frac{\partial f(z)}{\partial z}=0$

The method was tested by Leon et al. (2006) in four gauge stations on the Negro river main stream by comparing measured and estimated equivalent water depth. Also, the estimated water depth and ADCP (Acoustic Doppler Current Profiler) measurements collected at each virtual stations during a field campaign in May 2005 were compared.

In our case, the calculated equivalent water depth at virtual stations was compared to the nearest gauged mean water depth of Guaquira, Santa Isabel, Maria Manteca and Bacuri stations. Water depths at gauging stations vary with water stage at the time of measurement. Comparison between our $z$ estimate at virtual stations and water depth at in-situ gauges requires that both stations refer to an equivalent hydrological situation. We estimated a reference water depth at the gauge corrected for the time variations by computing the stage given by the local stage-discharge relationship using the measured discharges at local station and $a$ and $b$ of nearest virtual station. Differences between measured water depth and estimated water depth were expressed by

Hydrological parameter from satellite altimeter data

J. G. Leon

Title Page

Abstract Introduction

Conclusions

Tables References Figures

14

4

Back

Close

Full Screen / Esc

Printer-friendly Version

Interactive Discussion 
a bias:

$B_{(G S / V S)}=\frac{\sum\left|P_{i}-P_{i}^{\prime}\right|}{N}$

HESSD

Where, $\mathrm{B}_{(G S / V S)}$ represent the bias water depth difference between gauged station and nearest virtual station. $P_{i}$ is the measured water depth at local station at time $i, P_{i}^{\prime}$ 5 is the estimated water depth at local station at time $i$ using measured flow and $a$ and $b$ coefficients of calculated rating curve from virtual station. $N$ is the total number of measurements.

\section{Slopes and along stream profile}

10

Finally, a profile of the river bottom has been interpolated from the successive heights of zero flow estimates. This profile is referenced to GCM02C geoid model (Tapley et al., 2004).

\section{Results and discussion}

\subsection{Virtual stations over the Caqueta river main stream}

Virtual stations are shown in Fig. 3. They correspond to the intersection of either T/P or ENVISAT crossings with Caqueta river. We could define 13 virtual stations. 12 rely on ENVISAT and only 1 on T/P. The main characteristics of each station are summarized in Table 3.

3.2 Discharge estimations at virtual stations using PROGUM.

ProGUM uses Eqs. (1), (3) and (4) to estimate the discharge at time $t$, and the $K$ and $X$ parameters at each virtual station. Based on Eq. (1) the model can be expressed

Hydrological parameter from satellite altimeter data

J. G. Leon

Title Page

Abstract Introduction

Conclusions References

Tables Figures

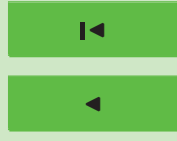

$\rightarrow$

Back

Close

Full Screen / Esc

Printer-friendly Version

Interactive Discussion 
as:

$Q_{o t}=C_{0}\left[Q_{i n}+Q_{t r}\right]_{t}+C_{1}\left[Q_{i n}+Q_{t r}\right]_{t-1}+C_{2}\left[Q_{o}\right]_{t-1}+C_{3}\left[q_{L} \cdot \Delta x\right]$

HESSD

Where $C_{0}, C_{1}, C_{2}$ and $C_{3}\left(C_{i}\right.$ coefficients) are the coefficients of Eqs. (2a-d) respectively. $Q_{i n}$ is the input from upriver, $Q_{t r}$ the sum of imported flow from tributaries, $Q_{0}$ 5 stands for the output flow at downstream end.

In our case, $q_{L}$ in Eq. (10) is estimated by adjusting the flow routing model to the local output hydrogram from Villa Betancourt station and input hydrogram estimated by influence drained area before Guaquira station. $Q_{t r}$ was derived using the same methodology of drained area.

10 After estimating $q_{L}$ for the total reach, and assuming a uniform distribution along the reach, PROGUM allows the outflows $Q_{O}$ to be estimated at any time $t$ and at any cross section in the main reach from estimated values of $Q_{i n}, Q_{t r}, q_{L}$ and known values of $\Delta x$ in Eq. (10). In this case, $\Delta x$ is the length of the considered portion of reach. Other parameters of Eqs. (3) and (4) are kept constant and the updated $C_{i}$ coefficients can be calculated. Previously, we defined those tributaries participating in the inflows for the considered reach to estimate the equivalent $Q_{t r}$. The estimated $Q_{o}$ at the downstream outlet will be the $Q_{i n}$ for the next reach.

For all Caqueta in-situ cross sections, a good agreement has been found between predicted and measured discharges during the calibration period, e.g., from 1980 to 20 2004. Calculated and measured mean outflow discharges are listed in Table 4, along with the $\Delta x$ used to adjust $q_{L}, \Delta x$ being used for the routing model and the mean values of $Q_{t r}$ and $Q_{L}$ at each step between in-situ stations.

In addition, Table 5 lists the mean absolute error based on measured outflow (Eq. 5a) and maximum and minimum flow difference (Eq. $5 b)$ for each reach. All error criteria 25 remain below $20 \%$ that is, below the flow rate measurement accuracy. Figures 4 a to $f$ show the differences between measured and calculated discharges at gauged local stations.

Errors at the in-situ stations are less than $20 \%\left(E_{1}\right)$ and $10 \%\left(E_{2}\right)$. Larger errors found at reach between Guaquira and Puerto Brisas stations show the limits of the 3036

Hydrological parameter from satellite altimeter data

J. G. Leon

Title Page

Abstract

Conclusions

Tables

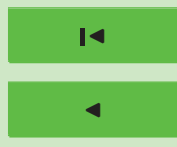

Back

Introduction

References

Figures

$\rightarrow$

$\checkmark$

Close

Full Screen / Esc

Printer-friendly Version

Interactive Discussion

EGU 
methodology applied. Leon et al. (2006) $)^{1}$ discuss an assumed uniform distribution of $Q_{L}$ limits to provide an estimate of outflow at any cross section. Indeed, if the $Q_{L}$ estimation is carried out between two stations far from each other, the assumed uniform distribution is no longer valid. Also, the tributary discharge estimated may vary 5 greatly from the upstream end to the downstream end. Also worthy of note is that in our study estimated remote discharges were predicted using only one gauged in-situ station (Villa Betancourt) at the outlet of the basin inducing considerable errors in the input hygrogram.

\subsection{Water stage estimates from altimetric data and estimated discharges}

10 The temporal series of altimetric heights for stations E293, T102 and E164 are an example of water stages obtained from the processing of ENVISAT (Figs. 5a and c) and T/P data (Fig. 5f). Height variations are typical of a unimodal tropical regime. Additionally, Figs. $5 \mathrm{a}$ to $5 \mathrm{e}$ show that discharge variations are clearly related to water levels variations. Despite the short measurement period for ENVISAT, the annual cycle of water levels is also clearly monitored, and discharge is correctly simulated by the model (Figs. $5 \mathrm{a}-\mathrm{c}$ ). Similar results have been obtained for all stations. Rating curves have been computed according to the described methodology.

\subsection{Rating curve and water depth estimation at virtual stations}

Following the methodology proposed by Leon et al. (2006) we estimated the 20 stage/discharge relationship and equivalent water depth at the thirteen identified virtual stations. Table 6 summarizes the results of the computed rating curve and the average water depth at these stations. In addition, the rating curve parameters used at in-situ stations to predict discharges from stage in-situ measurements have been listed. Figure 6 shows an example of rating curve obtained for some virtual stations.
HESSD

3, 3023-3059, 2006

Hydrological parameter from satellite altimeter data

J. G. Leon

Title Page

Abstract Introduction

Conclusions

Tables

References

Figures

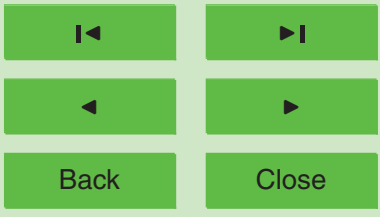

Full Screen / Esc

Printer-friendly Version

Interactive Discussion 


\subsubsection{Reliability assessment of rating curve parameters}

With the exception of ENVISAT station E751, correlation coefficients for all rating curves are adequate for virtual stations (>0.84), even for T/P station (0.94). T/P altimeter data are known to be more scattered than ENVISAT ones over rivers (Frappart 5 et al., 2006). Because of the higher scatter in the T/P measurements, rating curves at virtual stations are often derived with a correlation coefficient less than 0.8 (Leon et al., 2006).

Rantz et al. (1982) outlined that the stage-discharge relationship is governed by a unique set or combination of physical elements occurring downstream from the station, 10 refered to as controls. $b$ coefficient values reported in Table 6 account for these types of controls. They can be divided into two groups: section control (when $b>2$ ) and channel control (when $b<2$ ). On the one hand, $b$ values less than 2 are found at stations E422 and E794. This suggests that reaches at these stations are channel-controlled and their geometry and roughness govern the stage-discharge relationships. On the other hand, the reach from E293 to E751 is clearly section-controlled. In other words, geometry at these cross sections follows a channel constriction or downward break in bed slope located downstream from these stations (Rantz et al., 1982). The value of $\mathrm{b}$ found at these virtual stations may be corroborated by that of the stage-discharge relationship from Santa Isabel station $(b=2.46)$ located between T102 and E751.

20 This $195 \mathrm{~km}$ long section control is due to three broken slopes at Quinche waterfalls between E794 and E293, Tijereto waterfalls between E293 and E250/T102; and Solarte waterfalls between Santa Isabel station and E751. These breaks in slope are evidenced in the $z$ values (Table 6) . Figure 7 shows these slope changes over a map of Colombian hydrology published by IDEAM on 1986. The representation of the bot25 tom slope profile for the Caqueta main stream derived from values of $z$ in Table 6, also allows these downward breaks in bed slope to be indentified.

Values of coefficient $a$ in Table 6 are strongly associated with three characteristics of channel control: friction slope $(S)$, Manning roughness coefficient $(n)$ and mean width

\section{HESSD}

3, 3023-3059, 2006

\section{Hydrological} parameter from satellite altimeter data

J. G. Leon

Title Page

Abstract Introduction

Conclusions

Tables

References Figures

14

4

Back

Close

Full Screen / Esc

Printer-friendly Version

Interactive Discussion 
of cross section (W) (Rantz et al., 1982; Leon et al., 2006). In all studied station but E250, the variations of $a$ along the reaches are consistent with cross section changes, slope changes and tributary inputs. For example, the reach between E880 and E379; and from E293 to Santa Isabel station has values of a below 100. These values are 5 lied to changes in friction slopes in this section. The rating curve at E250 was derived with only 8 ENVISAT measurements. The particular results at this station need to be confirmed or updated with more satellite data when available.

3.4.2 Validation of derived rating curves at virtual stations by comparation with measured in-situ data

10 In order to validate the coefficients of stage/discharge relationship obtained at virtual stations, the estimated zero flow at corresponding cross sections, we compared the water depth obtained at in-situ station using measured flow at this station and the $a$ and $b$ coefficients from rating curve of the nearest virtual station.

Based on Eq. (9), this procedure was applied only at local stations where the closest 15 virtual station are not influenced by long distances $(<10 \mathrm{~km})$, broken slopes, cross section changes or outflow from important tributaries. This validation could be only conducted at stations related in Table 7 .

The good agreement in mean significant differences $(<1.05 \mathrm{~m})$ between MWD and EWD at the cross sections listed in Table 7 can be related to two main facts: the good 20 reliability of the methods proposed by Leon et al. (2006) ${ }^{1}$ and Leon et al. (2006) to estimate remote discharge and rating curves at virtual stations respectively, and the high quality of the altimeter data. More spatial data, especially ENVISAT data, are required to reinforce and validate the rating-curves of all virtual stations.

Based on the reasons given in the preceding section (only 8 measurements), stations 25 E250 was not compared with Santa Isabel measurements as was done with T102 located in the same area.

\section{HESSD}

3, 3023-3059, 2006

Hydrological parameter from satellite altimeter data

J. G. Leon

Title Page

Abstract Introduction

Conclusions

Tables References Figures

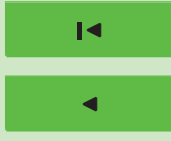
$\rightarrow$ I

Back

Close

Full Screen / Esc

Printer-friendly Version

Interactive Discussion 


\subsection{Bottom slope of the Caqueta main stream}

The average bottom slope of the Caqueta river can be calculated based on the equivalent zero effective flow estimations at virtual stations presented in Table 6 (Fig. 8).

An average bottom slope of $1.2 \times 10^{-4} \mathrm{~m} \mathrm{~m}^{-1}$ was calculated from station E422 to

5 station E164 referenced to GCM02C geoid model (Tapley et al., 2004). However, the river slope is not uniform and several breaks affect the altitude profile of the river. For example, a slope of $3.9 \times 10^{-4} \mathrm{~m} \mathrm{~m}^{-1}$ was estimated between E379 and E837. At this section of the river, using the same map presented in Fig. 7, three different waterfalls can be identified: Guamarayas, Cuemani and Angosturas. Table 8 summarizes all slope changes for each reach involving virtual stations considered in Table 6 . With a denser network of stations owing to the addition of virtual stations, the method even allows us to track the major changes in bed slope that cannot be identified with gauged in-situ measurements.

Conversely, the profile does not show any change in bed slope between T102 and 15

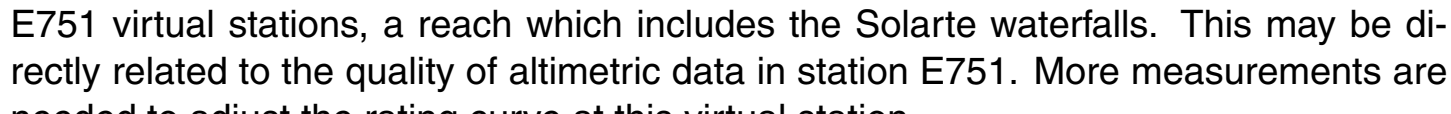
needed to adjust the rating curve at this virtual station.

\section{Conclusions}

Compared to the previous study, where the method was applied to the Negro River, the basin studied is characterized by a very irregular geometry and discharge. Upstream from Maria Manteca station, river width is not in excess of $1.10 \mathrm{~km}$, even in the rainy season (Negro River presents cross section widths over $2 \mathrm{~km}$ during this season). The river width as well as the steep topography detrimentally affect the quality of the altimetric data (Frappart, 2006; Leon et al., 2006).

$25 \quad$ A unique downstream in situ gaging station has been considered, the other being used for validation purposes. Nethertheless, this study corroborates some of the most
HESSD

3, 3023-3059, 2006

Hydrological parameter from satellite altimeter

data

J. G. Leon

Title Page

Abstract

Introduction

Conclusions

Tables

References

Figures

14

4

Back

Close

Full Screen / Esc

Printer-friendly Version

Interactive Discussion 
important applications of spatial altimetry in hydrology presented by Leon et al. (2006) including rating curve estimation at virtual station, the derived equivalent water depth at these cross sections and bottom slope profile of considered reaches. For example, propagated flow errors below $20 \%$ (taking in account the error related to the estimation

5 of input hydrograph), derived rating curves at virtual stations with a correlation coefficient over 0.84, bias between MWD and EWD below $1.05 \mathrm{~m}$; and finally, it was possible to identify and quantify the most important broken slopes of the Caqueta main stream. Despite the quality of altimetric data that could be improved in some virtual stations when more measurements will be available, all results show a good level of accuracy.

10 The rating-curve were estimated for 13 virtual stations at Caqueta river main stream: 12 from ENVISAT data, with two stations (E751 and E250) exhibiting poor quality altimetric data; and one from T/P with very good quality, unlike what was expected from these measurements as discussed in a previous section.

The proposed methodology allows us to determine highly valuable parameters for 15 flow propagation process assessment. It is the authors'opinion that the developed methodology is now ready for use as support in future works on the Amazon Basin and related zones as a complement of in-situ data to monitor and model inland waters.

Acknowledgements. This study was funded by the CASH project from the "Réseau Terre \& Espace" of the French Ministry of Research and Technology (MRT decision n 04 T 131), and 20 by the ECCO PNRH MESBAM project. Altimetry data were retrieved from Centre de Topographie d'Océan et Hydrologie (CTOH) at LEGOS. We are very grateful to IDEAM, especially to $\mathrm{H}$. Romero, and C. Gonzalez from Universidad Nacional de Colombia, for preparing and sending all the hydrological in-situ information needed for the study. We are also grateful to TOSCA "hydrologie spatiale". Finally, our thanks go to J.-L. Guyot for his invaluable suggestions based

\section{References}

Berry, P. A.: Global river and lake monitoring from multimission altimetry: capability and potential, The Abstracts of the Workshop Hydrology from Space, 29 September-1 October 2003,

HESSD

3, 3023-3059, 2006

\section{Hydrological} parameter from satellite altimeter data

J. G. Leon

Title Page

Abstract Introduction

Conclusions

Tables

References

Figures

14

4

Back

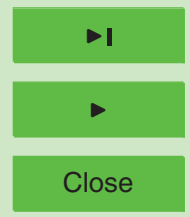

Full Screen / Esc

Printer-friendly Version

Interactive Discussion

EGU 
Toulouse, France, 2003.

Birkett, C.: The contribution of TOPEX NASA radar altimeter to the global monitoring of large rivers and wetlands, Water Resour. Res., 34, 1223-1239, 1998.

Birkett, C. M., Mertes, L. A., Dunne, T., Costa, M., and Jasinski, J.: Altimetric remote sensing 5 of the Amazon: Application of satellite radar altimetry, J. Geophys. Res., 107(D20), 8059, doi:10.1029/2001JD000609, 2002.

Bjerklie, D. M., Dingman, S. L., Vorosmarty, C. J., Bolster, C. H., and Congalton, R. G.: Evaluating the potential for measuring river discharge from space, J. Hydrol., 278(14), 17-38, 2003.

10 Coe, M., Costa, M., Botta, A., and Birkett, C. M.: Long-term simulations of discharge and floods in the Amazon Basin, Geophys. Res., 107(D20), 8044, doi:10.1029/2001JD000740, 2002.

Costa, M. and Foley, J.: Water balance of the Amazon Basin: Dependence on vegetation cover and canopy conductance, Geophys. Res., 102(D23), 973-989, 1997.

Costa, M., Oliveira, C., Andrade, R., Bustamante, T., and Silva, F.: A macroscale hydrological data set of river flow routing parameters for the Amazon Basin, Geophys. Res., 107(D20), 8039, doi:10.1029/2001JD0309, 2002.

Cunge, J. A.: On the Subject of a Flood Propagation Computation Method (Muskingum Method), Hydraulic Res., 7(2), 205-230, 1969.

Frappart, F., Calmant, S., Cauhope, M., Seyler, F., and Cazenave, A.: Preliminary results of ENVISAT RA-2-derived water levels validation over the Amazon Basin, Remote Sensing Environ., 100(2), 252-264, 2006.

Frappart, F., Seyler, F., Martinez, J.-M., León, J.G., and Cazenave, A.: Determination of the Water Volume Variation in the Negro River Sub-Basin by Combination of Satellite and In-Situ Data, Remote Sensing of Environment, 99, 387-399, 2005.

Leon, J. G., Calmant, S., Seyler, F., Bonnet, M. P., Cauhope, M., Frappart, F., and Filizola, N.: Rating curves and estimation of average water depth at the Upper Negro River based on satellite altimeter data and modelled discharges, J. Hydrol., in press, 2006.

Ponce, V. M.: Diffusion wave modelling of catchment dynamics, J. of the Hydraulics Division, ASCE, 112(8), 716-727, 1986.

30 Ponce, V. M., Lohani, A., and Scheyhing, C.: Analytical verification of Muskingum-Cunge routing, J. Hydrol., 174, 235-241, 1996.

Rantz, S. E.: Measurement and computation of streamflow. Measurement of Stage and Discharge, U.S. Geological Survey Water Supply Paper, 1, 284, 1982.
HESSD

3, 3023-3059, 2006

\section{Hydrological} parameter from satellite altimeter

data

J. G. Leon

Title Page

Abstract

Introduction

Conclusions

Tables

References

Figures

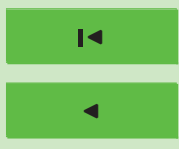

$>1$

Back

Close

Full Screen / Esc

Printer-friendly Version

Interactive Discussion 
Perez, R. C., Chelton, D. B.,and Miller, R. N..: The Effects of Wind Forcing and Background Mean Currents on the Latitudinal Structure of Equatorial Rossby Waves, J. Phys. Oceanography, 35(5), 666-682, 2005.

Richey, J., Mertes, A., Dunne, T., Victoria, R., Forsberg, B., Tancredi, A., and Oliveira, E.: Sources and routing of the Amazon River flood wave, Global Biochemical Cycles, 3(3), 191204, 1989.

Tapley, B. D., Bettadpur S., Watkins, M. M., and Reigber C.: The Gravity Recovery and Climate Experiment: Mission Overview and Early Results, Geophys. Res. Lett., 31, L09607, doi:10.1029/2004GL019920, 2004.

HESSD

3, 3023-3059, 2006

\section{Hydrological parameter from satellite altimeter data}

J. G. Leon

\section{Title Page}

Abstract

Conclusions

Tables

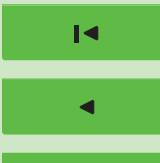

Back
Introduction

References

Figures

- I

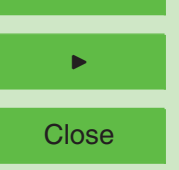

Full Screen / Esc

Printer-friendly Version

Interactive Discussion 


\section{HESSD}

3, 3023-3059, 2006

\section{Hydrological parameter from satellite altimeter data}

Table 1. Principal characteristics of gauged in-situ stations in Caqueta main stream.

J. G. Leon

\begin{tabular}{|c|c|c|c|c|c|c|}
\hline Station Name & Long. & Lat. & $\begin{array}{l}\text { Available discharge } \\
\text { period measurement }\end{array}$ & $\begin{array}{l}\text { Range of measured } \\
\text { Discharge }\left(\mathrm{m}^{3} / \mathrm{s}\right)\end{array}$ & $\begin{array}{l}\text { Drained } \\
\text { area } \mathrm{km}^{2}\end{array}$ & use \\
\hline Guaquira & -74.04 & -0.33 & $\begin{array}{l}25 \text { Jan } 95-16 \text { April } 98 \\
\text { with several interruptions }\end{array}$ & $790-7900$ & 53636 & validation \\
\hline Puerto Brisas & -72.46 & -0.58 & 01 Jan 95-31 Dec 2000 & 850-9200 & 68132 & validation \\
\hline Santa Isabel & -71.09 & -1.12 & 01 Jan 95-31 Dec 2000 & $1550-15000$ & 111292 & validation \\
\hline Maria Manteca & -70.61 & -1.42 & 01 Jan 95-31 Dec 2000 & $1650-17500$ & 129066 & validation \\
\hline Bacuri & -68.47 & -1.21 & 01 Jan 95-31 Dec 2000 & $1800-19800$ & 144098 & validation \\
\hline Villa Betancourt & -69.41 & -1.40 & 14 March 80-30 March 04 & 2000-33400 & 199090 & modelling \\
\hline
\end{tabular}

Title Page

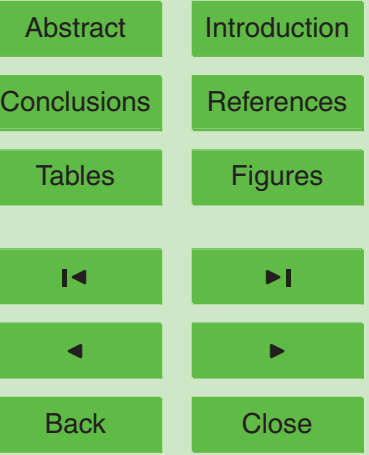

Full Screen / Esc

Printer-friendly Version

Interactive Discussion 


\section{HESSD}

3, 3023-3059, 2006

Table 2. Main characteristics of T/P and EVISAT missions.

\begin{tabular}{lcc}
\hline Mission & T/P & ENVISAT \\
\hline Launched date & Aug $1992^{*}$ & March 2002 \\
Orbit & $1336 \mathrm{~km}$ & $800 \mathrm{~km}$ \\
Inclination & $66^{\circ}$ & $98.5^{\circ}$ \\
Temporal resolution & 10 days & 35 days \\
Spatial resolution at equatorial regions & $315 \mathrm{~km}$ & $85 \mathrm{~km}$ \\
rate of measured values & $10 \mathrm{~Hz}$ & $18 \mathrm{~Hz}$ \\
Available cycles & $354^{*}$ & 31 at the beginning of the study \\
& & \\
tracking algorithms & ocean & Ice1, Ice2, Ocean and Sealce \\
Considered tracks in this study & 102 & $164,207,250,293,379,422$, \\
& & $708,751,794,837,880,923$ \\
\hline
\end{tabular}

${ }^{*}$ On September 2002 T/P moved to a new orbit midway between its original ground tracks. The former T/P ground tracks are now overflown by Jason-1. Only 60 cycles of data are available for this new orbit.

\section{Hydrological parameter from satellite altimeter data}

J. G. Leon

Title Page

Abstract Introduction

Conclusions References

Tables Figures

14

4

Back

Printer-friendly Version

Interactive Discussion 


\section{HESSD}

3, 3023-3059, 2006

\section{Hydrological parameter from satellite altimeter data}

Table 3. Main characteristics of the virtual stations.

\begin{tabular}{ccccccc}
\hline Station & River & Lat/Long & Type of data & $\begin{array}{c}\text { Dry/wet season } \\
\text { cross-sec. width }(\mathrm{km})\end{array}$ & $\begin{array}{c}\text { Nearest local } \\
\text { station }\end{array}$ & $\begin{array}{c}\text { Distance to nearest } \\
\text { local station }(\mathrm{km})\end{array}$ \\
\hline E422 & Caqueta & $-0.36 /-73.96$ & ENVISAT & $0.73 / 0.75$ & Guaquira & 9.75 \\
E923 & Caqueta & $-0.41 /-73.80$ & ENVISAT & $0.82 / 0.83$ & Guaquira & 27.25 \\
E880 & Caqueta & $-0.57 /-73.27$ & ENVISAT & $0.75 / 0.82$ & Guaquira & 110.63 \\
E379 & Caqueta & $-0.53 /-73.05$ & ENVISAT & $0.91 / 0.92$ & Pto Brisas & 86.70 \\
E837 & Caqueta & $-0.63 /-72.31$ & ENVISAT & $0.72 / 0.65$ & Pto Brisas & 25.75 \\
E794 & Caqueta & $-0.78 /-71.89$ & ENVISAT & $1.10 / 1.13$ & Pto Brisas & 95.60 \\
E293 & Caqueta & $-1.13 /-71.47$ & ENVISAT & $1.01 / 1.01$ & Santa Isabel & 51.03 \\
E250 & Caqueta & $-1.04 /-71.22$ & ENVISAT & $1.01 / 1.02$ & Santa Isabel & 18.41 \\
T102 & Caqueta & $-1.04 /-71.20$ & T/P & $1.01 / 1.02$ & Santa Isabel & 16.50 \\
E751 & Caqueta & $-1.43 /-70.71$ & ENVISAT & $1.26 / 1.42$ & Maria Manteca & 11.14 \\
E708 & Caqueta & $-1.40 /-70.58$ & ENVISAT & $1.57 / 1.58$ & Maria Manteca & 2.44 \\
E207 & Caqueta & $-1.39 /-69.98$ & ENVISAT & $1.96 / 1.96$ & Bacuri & 81.01 \\
E164 & Caqueta & $-1.21 /-69.81$ & ENVISAT & $2.49 / 2.49$ & Bacuri & 47.98 \\
\hline
\end{tabular}

J. G. Leon

Title Page

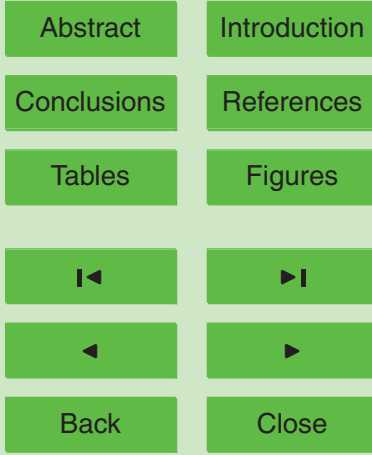

Full Screen / Esc

Printer-friendly Version

Interactive Discussion 


\section{HESSD}

3, 3023-3059, 2006

Table 4. Calculated and measured mean discharges, $\Delta x$ to adjust $q_{L}, \Delta x$ for routing processes, $Q_{t r}$ and $Q_{L}$ at each step in the routing model.

\begin{tabular}{|c|c|c|c|c|c|c|c|}
\hline $\begin{array}{l}\text { In-situ station or } \\
\text { virtual station name }\end{array}$ & $\begin{array}{c}\Delta x \text { to calibrate } \\
\quad \mathrm{q}_{L}(\mathrm{~km})\end{array}$ & $\begin{array}{c}\Delta x \text { for } \\
\text { routing }(\mathrm{km})\end{array}$ & $\begin{array}{c}\text { Mean } Q_{i n} \\
\left(\mathrm{~m}^{3} / \mathrm{s}\right)\end{array}$ & $\begin{array}{c}\left.\text { Mean } Q_{t r}\right) \\
\left(\mathrm{m}^{3} / \mathrm{s}\right.\end{array}$ & $\begin{array}{c}\left.\text { Mean } Q_{L}\right) \\
\left(\mathrm{m}^{3} / \mathrm{s}\right.\end{array}$ & $\begin{array}{c}\text { Mean } Q_{O} \text { calc. } \\
\left(\mathrm{m}^{3} / \mathrm{s}\right)\end{array}$ & $\begin{array}{c}\text { Mean Qmeas. } \\
\left(\mathrm{m}^{3} / \mathrm{s}\right)\end{array}$ \\
\hline Guaquira & & & 3576 & & & & 3821 \\
\hline E422 & & 9,75 & & 0 & 142 & 3717 & \\
\hline E923 & & 17,5 & & 0 & 43 & 3764 & \\
\hline E880 & & 93,13 & & 0 & 181 & 3943 & \\
\hline E379 & & 36,97 & & 200 & 82 & 4230 & \\
\hline Pto. Brisas & & 86,70 & & 0 & 150 & 4379 & 4195 \\
\hline E837 & & 25,75 & & 0 & 97 & 4475 & \\
\hline E794 & & 69,85 & & 2369 & 153 & 7003 & \\
\hline E293 & & 83,66 & & 244 & 186 & 7435 & \\
\hline $\mathrm{E} 250$ / T102* & & 34,46 & & 68 & 77 & 7583 & \\
\hline Santa Isabel & & 16,50 & & 0 & 37 & 7622 & 7114 \\
\hline E751 & & 60,64 & & 981 & 135 & 8736 & \\
\hline Maria Manteca / E708* & & 11,14 & & 0 & 25 & 8759 & 8319 \\
\hline E207 & & 88,11 & & 201 & 196 & 9148 & \\
\hline E164 & & 33,03 & & 571 & 72 & 9844 & \\
\hline Bacuri & & 47,98 & & 0 & 107 & 9937 & 10078 \\
\hline Villa Betancourt & 736 & 20,44 & & 3667 & 46 & 13649 & 13621 \\
\hline
\end{tabular}

* Difference in distance between these two stations is less than $2 \mathrm{~km}$ without major tributaries. Thus, it is assumed that the stations are located at the same geographical point.

\section{Hydrological parameter from satellite altimeter data}

J. G. Leon

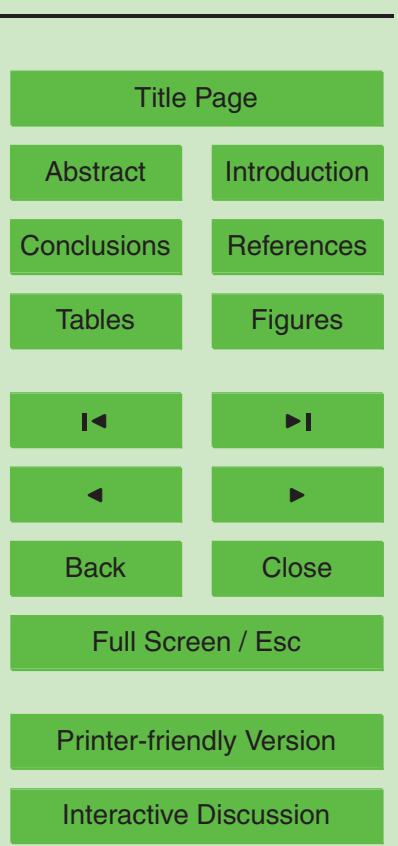




\section{HESSD}

3, 3023-3059, 2006

\section{Hydrological parameter from satellite altimeter data}

Table 5. Mean error based on measured outflow $\left(E_{1}\right)$ and maximum and minimum flow difference $\left(E_{2}\right)$ at gauged stations.

\begin{tabular}{lcc}
\hline stream outlet & $\mathrm{E}_{1}(\%)$ & $\mathrm{E}_{2}(\%)$ \\
\hline Guaquira & 20 & 9 \\
Pto Brisas & 17 & 6 \\
Santa Isabel & 14 & 5 \\
Maria Manteca & 10 & 4 \\
Bacuri & 10 & 4 \\
Villa Betancourt & 5 & 2 \\
\hline
\end{tabular}

J. G. Leon

Title Page

Abstract

Introduction

Conclusions

References

Tables

Figures

14

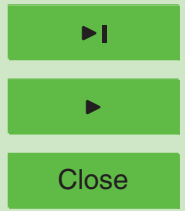

Back

Close

Full Screen / Esc

Printer-friendly Version

Interactive Discussion 
Table 6. Results of computed rating curves at virtual stations and measured rating curves at gauged local stations.

\begin{tabular}{ccccccc}
\hline Station & $a$ & $b$ & $Z$ & $R^{2}$ & $N$ & Average water depth \\
\hline Guaquira & 65.91 & 2.16 & - & 0.94 & 35 & 6.55 \\
E422 & 49.17 & 2.08 & 159.4 & 0.95 & 10 & 7.10 \\
E923 & 106.13 & 1.69 & 158.6 & 0.94 & 10 & 8.09 \\
E880 & 80.95 & 1.85 & 150.81 & 0.89 & 10 & 8.16 \\
E379 & 78.69 & 1.73 & 144.9 & 0.86 & 7 & 9.27 \\
Pto Brisas & 285.06 & 1.29 & - & 0.95 & 26 & 9.01 \\
E837 & 86.7 & 1.65 & 100.07 & 0,90 & 13 & 11.17 \\
E794 & 586.62 & 1.33 & 99.3 & 0.94 & 11 & 6.45 \\
E293 & 60.58 & 2.08 & 88,77 & 0.92 & 12 & 9.65 \\
E250 & 4.71 & 2.82 & 84.81 & 0.88 & 8 & 12.91 \\
T102 & 54.33 & 2.03 & 84.4 & 0.94 & 45 & 12.29 \\
Sta Isabel & 25.63 & 2.46 & - & 0.97 & 22 & 9.9 \\
E751 & 120.72 & 2.02 & 83.94 & 0.66 & 11 & 7.95 \\
M.Manteca & 218.84 & 1.75 & - & 0.76 & 20 & 8.37 \\
E708 & 244.18 & 1.76 & 81.69 & 0.88 & 11 & 6.94 \\
E207 & 141.55 & 2.00 & 74.75 & 0.84 & 11 & 7.08 \\
E164 & 815.16 & 1.29 & 73.85 & 0.88 & 13 & 6.48 \\
Bacuri & 240.56 & 1.76 & - & 0.97 & 16 & 8.47 \\
\hline
\end{tabular}

HESSD

3, 3023-3059, 2006

\section{Hydrological parameter from satellite altimeter data}

J. G. Leon

\section{Title Page}

Abstract

Conclusions

Tables

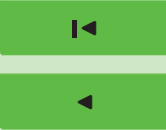

Back
Introduction

References

Figures

$\rightarrow$

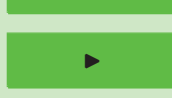

Close

$a$ : Rating curve coefficient of selected virtual station;

$b$ : rating curve coefficient of selected virtual station;

Full Screen / Esc

$Z$ : zero flow altitude from WGS84 ellipsoid;

$R^{2}$ : correlation coefficient;

Printer-friendly Version

$N$ : total number of measures at local station. 


\section{HESSD}

3, 3023-3059, 2006

Table 7. Bias estimation at gauged local stations from measured discharges and deduced a and $b$ coefficients of nearest virtual stations.

\begin{tabular}{lcccccccc}
\hline Local station & $\begin{array}{c}\text { Nearest } \\
\text { virtual station }\end{array}$ & $\begin{array}{c}\text { Distance between } \\
\text { stations }(\mathrm{km})\end{array}$ & $a$ & $b$ & $N$ & $\begin{array}{c}\text { Mean } \\
\text { MWD }\end{array}$ & $\begin{array}{c}\text { Mean } \\
\text { EWD }\end{array}$ & $\begin{array}{c}\text { RMSE } \\
(\mathrm{m})\end{array}$ \\
\hline Guaquira & $\mathrm{E} 422$ & 9.75 & 49.17 & 2.08 & 35 & 6.55 & 8.11 & 1.56 \\
Santa Isabel & $\mathrm{T} 102$ & 16.5 & 54.33 & 2.03 & 22 & 9.90 & 11.18 & 1.28 \\
M. Manteca & E751 & 11.14 & 120.72 & 2.02 & 20 & 8.37 & 8.19 & 0.18 \\
M. Manteca & E708 & 2.5 & 244.18 & 1.76 & 20 & 8.37 & 7.52 & 0.85 \\
Bacuri & E164 & 47.98 & 815.16 & 1.29 & 16 & 8.47 & 7.18 & 1.28 \\
\hline
\end{tabular}

\section{Hydrological parameter from satellite altimeter data}

J. G. Leon

a : Rating curve coefficient of selected virtual station;

$b$ : rating curve coefficient of selected virtual station;

$N$ : total number of measures at local station;

MWD: measured water depth at in-situ station;

EWD: estimated water depth at in-situ station using measured discharges and $a$ and $b$ coefficientsm

RMSE: Root Mean Square Error between.

Title Page

Abstract

Conclusions

Tables

Figures
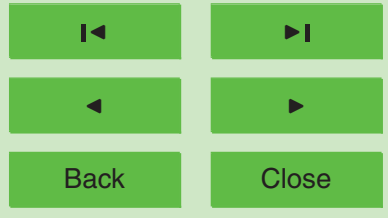

Full Screen / Esc

Printer-friendly Version

Interactive Discussion 


\section{HESSD}

3, 3023-3059, 2006

Table 8. Calculated bed slopes between virtual stations.

\begin{tabular}{ccc}
\hline Reach & Bottom slope $(\mathrm{m} \mathrm{m})^{-1}$ & Identified waterfalls \\
\hline E422-E923 & $3.88 \times 10^{-5}$ & - \\
E923-E880 & $7.831 \times 0^{-5}$ & - \\
E880-E379 & $1.50 \times 10^{-4}$ & - \\
E379-E837 & $3.91 \times 10^{-4}$ & Guamarayas, Cuemani, Angosturas \\
E837-E794 & $7,44 \times 10^{-6}$ & - \\
E794-E293 & $1.18 \times 10^{-4}$ & Quinche \\
E293-ET102 & $1.01 \times 10^{-4}$ & Tijereto \\
T102-E751 & $8.55 \times 10^{-7}$ & Solarte \\
E751-E708 & $1.47 \times 10^{-4}$ & - \\
E708-E297 & $6.88 \times 10^{-5}$ & - \\
E297-E164 & $1.21 \times 10^{-5}$ & Cordoba \\
\hline
\end{tabular}

\section{Hydrological parameter from satellite altimeter data}

J. G. Leon

Title Page

Abstract

Conclusions

Tables

14

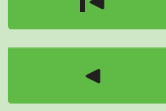

Back
Introduction

References

Figures

$\rightarrow$

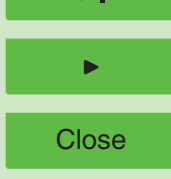

Full Screen / Esc

Printer-friendly Version 


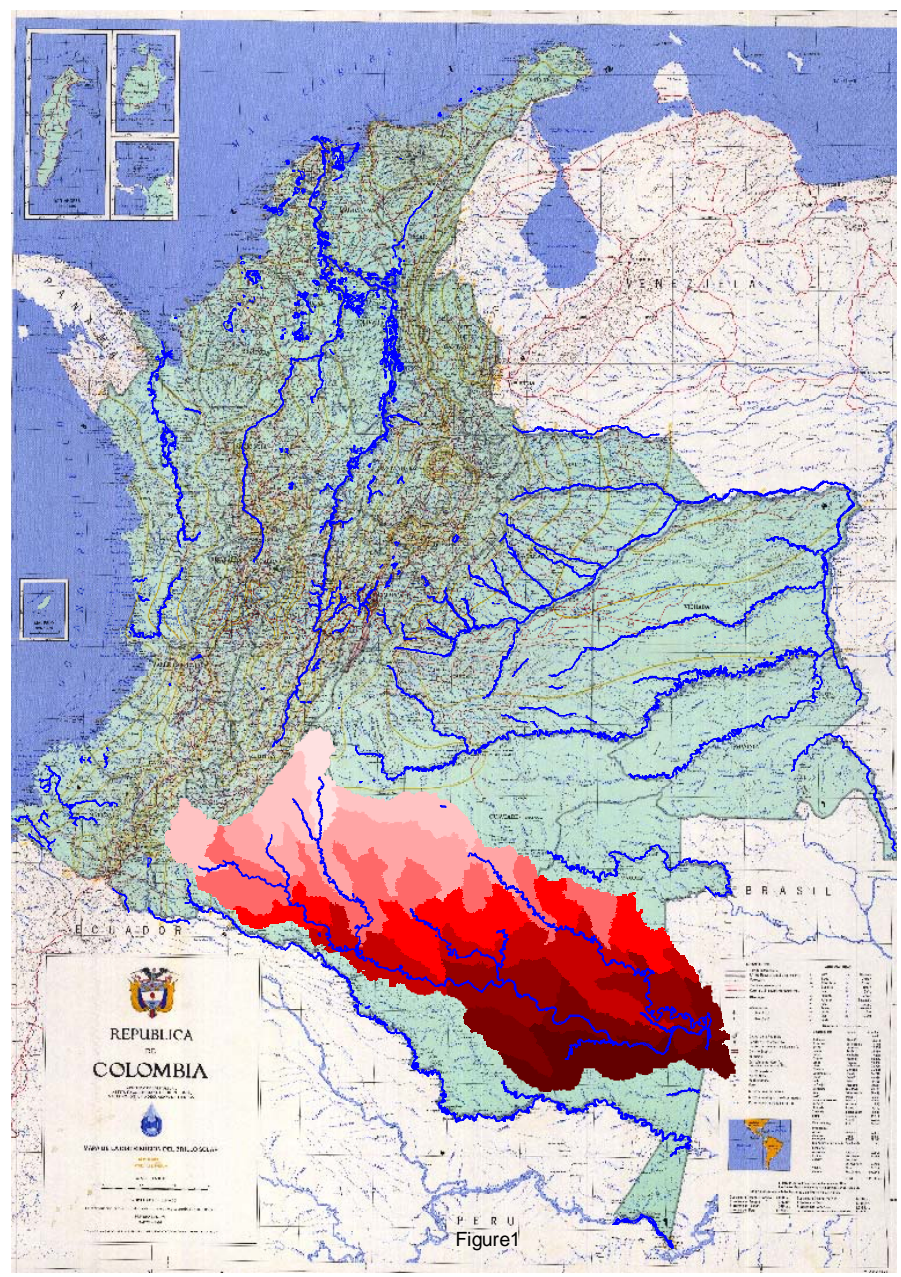

\section{HESSD}

3, 3023-3059, 2006

\section{Hydrological parameter from satellite altimeter data}

J. G. Leon

Title Page

Abstract

Conclusions

Tables

14

$<$

Back

Full Screen / Esc

Printer-friendly Version

Interactive Discussion

Fig. 1. Caqueta River Basin. 


\section{HESSD}

3, 3023-3059, 2006

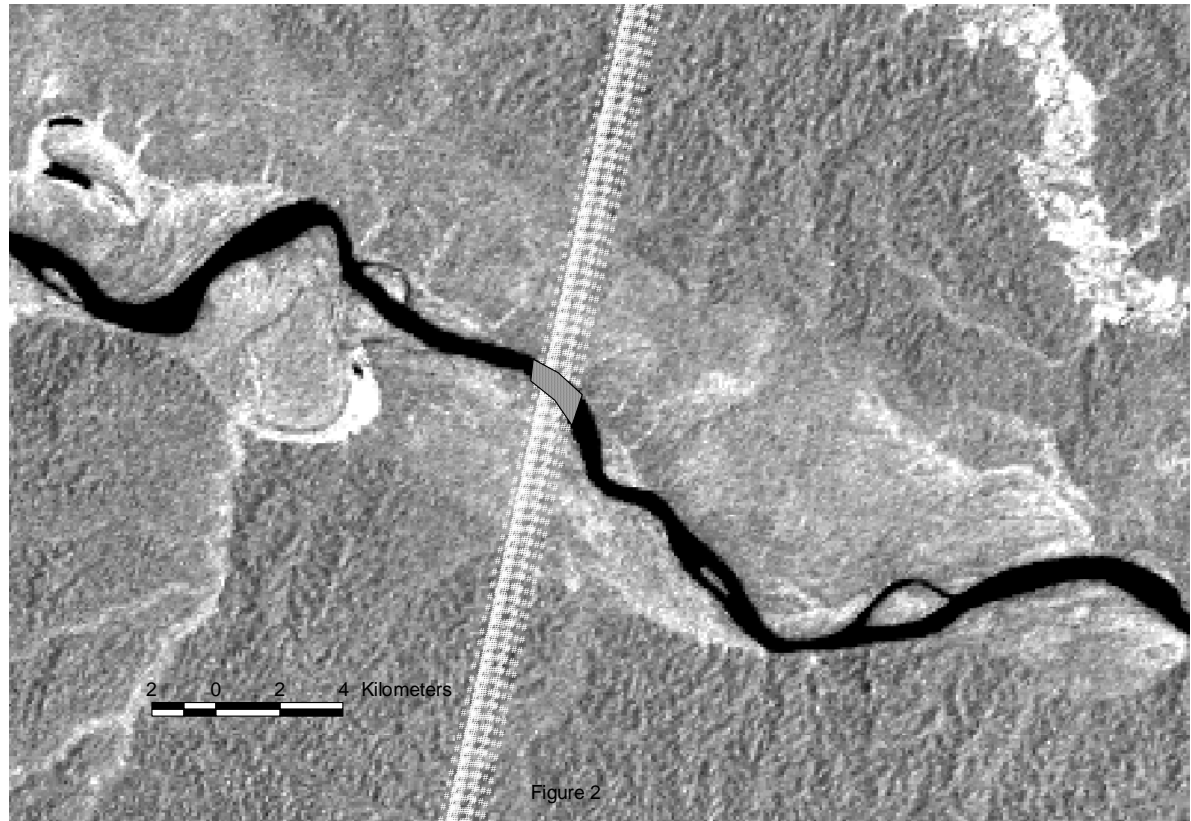

Fig. 2. Altimetric data from ENVISAT track 880 used to define virtual station E880 at Caqueta River mainstream.

\section{Hydrological parameter from satellite altimeter data}

J. G. Leon

Title Page

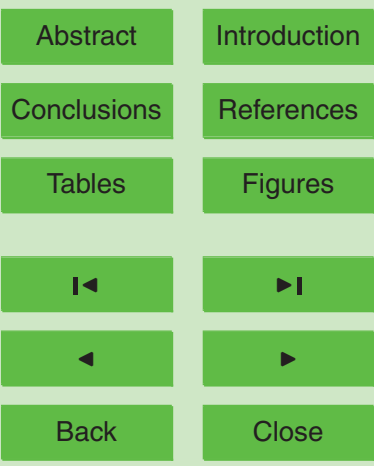

Full Screen / Esc

Printer-friendly Version

Interactive Discussion 
HESSD

3, 3023-3059, 2006

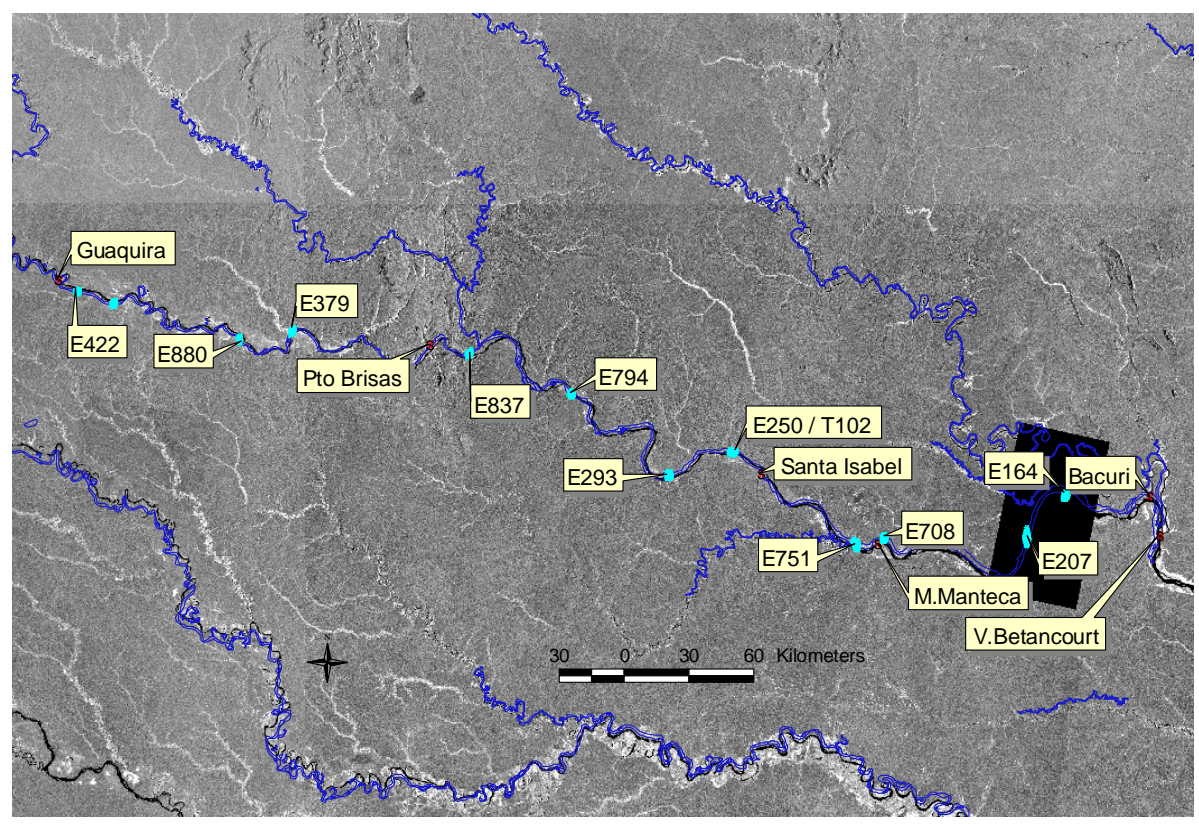

Fig. 3. Virtual gauged stations (blue dots) and in-situ gauged stations (red dots) location along the Caqueta main stream over a JERS image.

\section{Hydrological parameter from satellite altimeter data}

J. G. Leon

Title Page
Abstract

Conclusions

Tables

14

4

Back
Introduction

References

Figures

$>$ I

$>$

Close
Full Screen / Esc

Printer-friendly Version

Interactive Discussion 


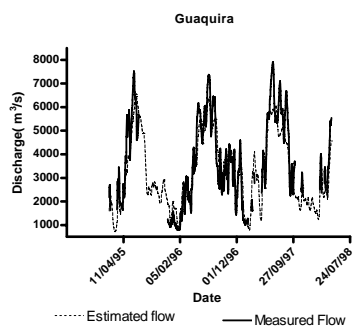

(a)

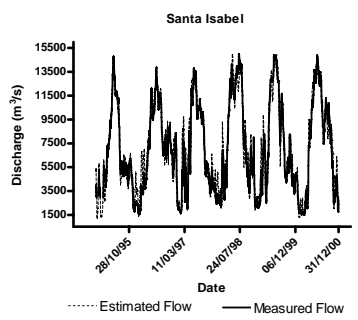

(c)

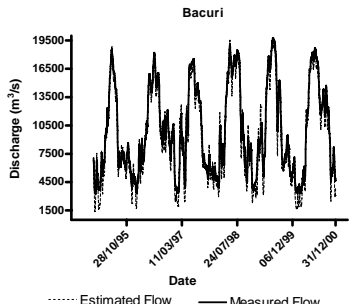

(e)

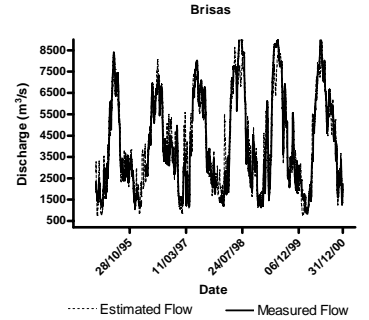

(b)

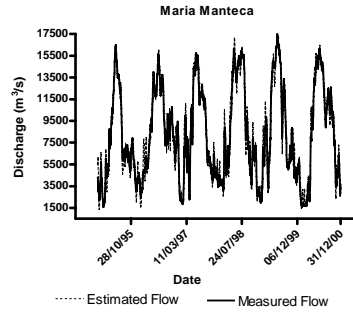

(d)

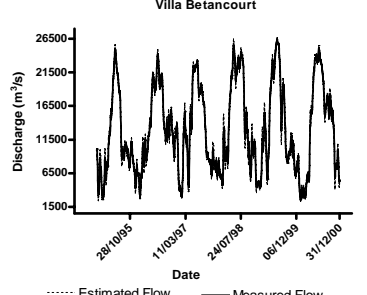

(f)
HESSD

3, 3023-3059, 2006

\section{Hydrological parameter from satellite altimeter data}

J. G. Leon

Title Page

Abstract

Introduction

Conclusions

References

Tables

Figures

14

$\rightarrow$ I

4

Back

Close

\section{Full Screen / Esc}

Printer-friendly Version

Fig. 4. Representation of measured flow and estimated flow at the local stations considered in the study. 


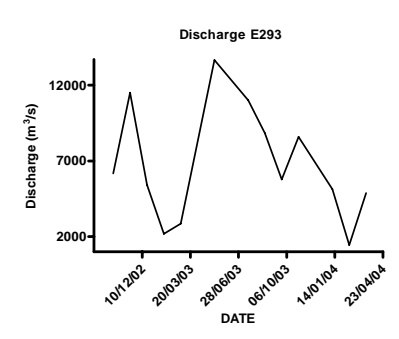

(a)

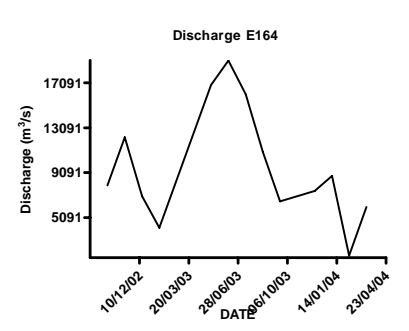

(c)

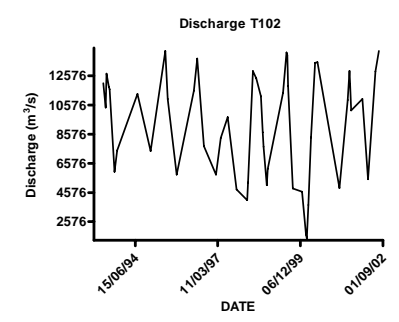

(e)

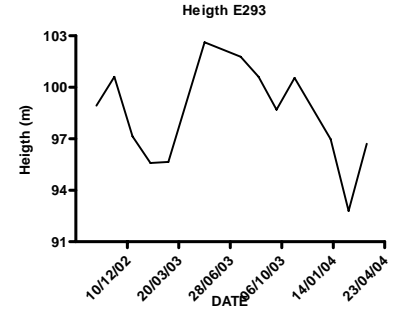

(b)

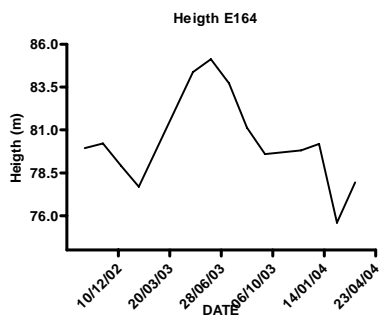

(d)

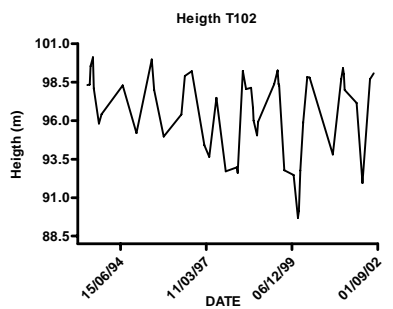

(f)

\section{HESSD}

3, 3023-3059, 2006

\section{Hydrological parameter from satellite altimeter data}

J. G. Leon

Title Page

Abstract

Introduction

Conclusions

References

Tables

Figures

14

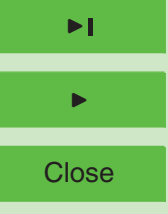

Back

Full Screen / Esc

Printer-friendly Version

Interactive Discussion

Fig. 5. Discharge and water stage time series of three virtual stations along the Caqueta main stream. 
E880

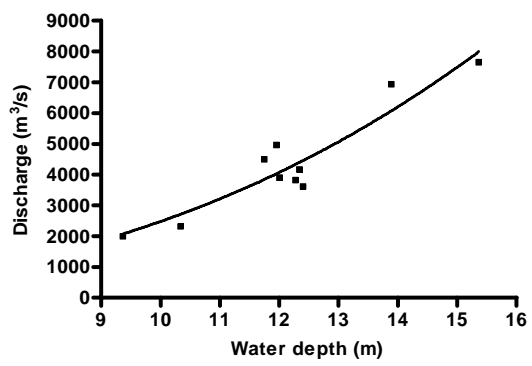

T102

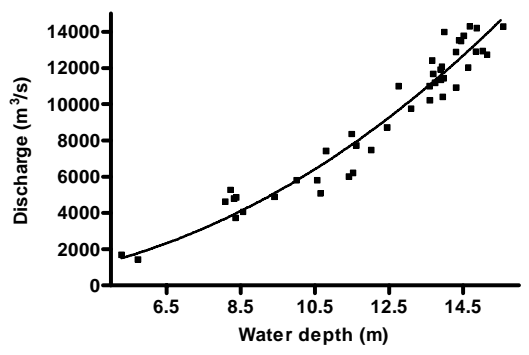

E293

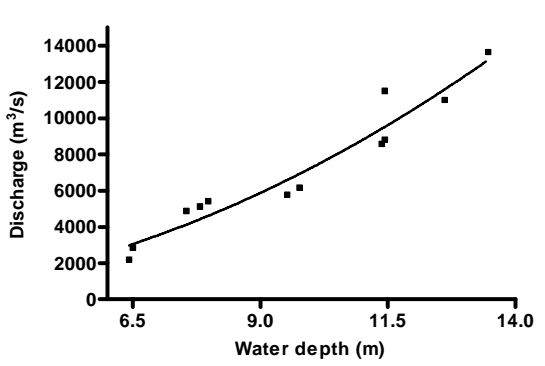

E164

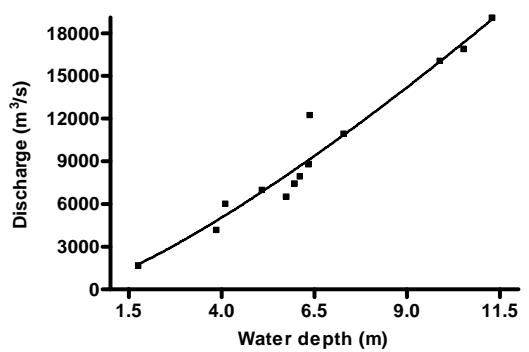

HESSD

3, 3023-3059, 2006

\section{Hydrological parameter from satellite altimeter data}

J. G. Leon

Title Page

Abstract

Conclusions

Tables

14

4

Back

Full Screen / Esc

Printer-friendly Version

Fig. 6. Examples of rating curves obtained for stations E880, E293, T102 and E164. 


\section{HESSD}

3, 3023-3059, 2006

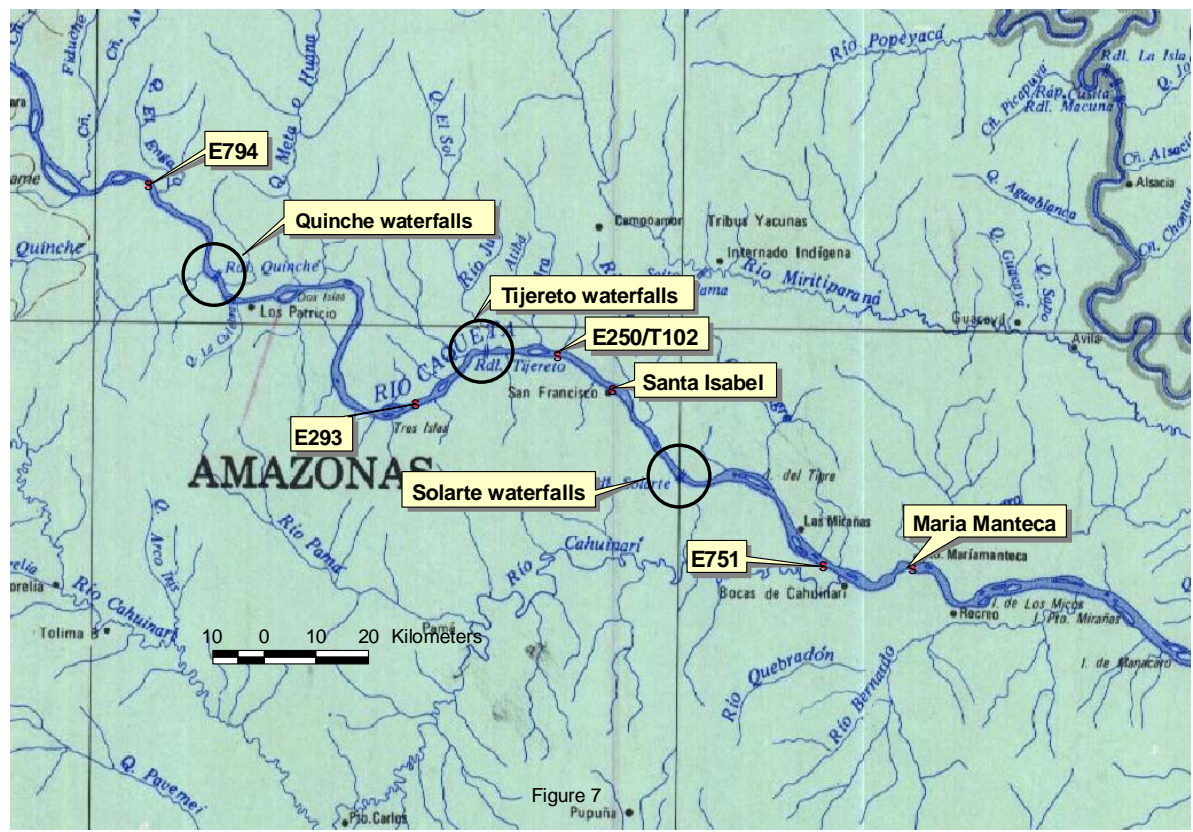

\section{Hydrological parameter from satellite altimeter data}

J. G. Leon

Title Page

\section{Abstract}

Conclusions

Tables

14

Back

Full Screen / Esc

Printer-friendly Version 


\section{HESSD}

3, 3023-3059, 2006

\section{Hydrological parameter from satellite altimeter data}

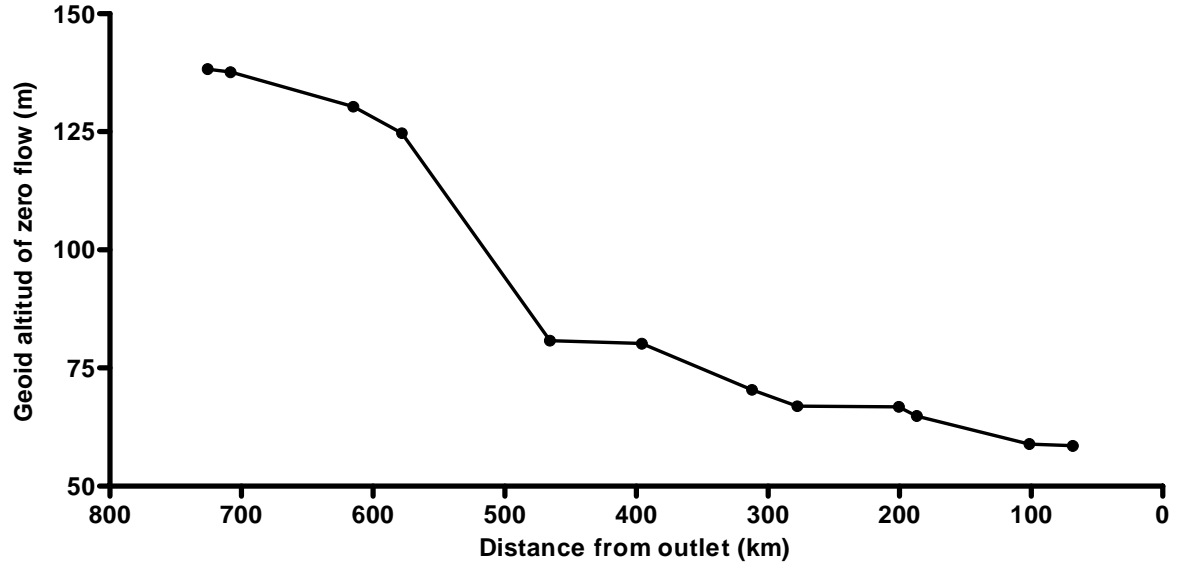

Fig. 8. Caqueta River bottom slope profile based on zero flow estimations at virtual stations.
J. G. Leon

Title Page

Abstract Introduction

Conclusions References

Tables Figures

14

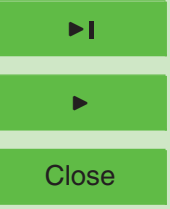

Back

Full Screen / Esc

Printer-friendly Version

Interactive Discussion 